\title{
DESAIN LANSKAP JALAN K.H. ABDULLAH BIN NUH BERBASIS GREEN STREET
}

\author{
Mauldy Ahmad Fadhillah \\ Departemen Arsitektur Lanskap, Fakultas Pertanian, Institut Pertanian Bogor (IPB) \\ mauldyahmad30@gmail.com

\section{Pingkan Nuryanti} \\ Departemen Arsitektur Lanskap, Fakultas Pertanian, Institut Pertanian Bogor (IPB) \\ pingkannuryanti@apps.ipb.ac.id
}

\begin{abstract}
Abstrak
Green Street adalah sebuah inovasi yang sangat penting dalam mengelola limpasan air dari paving atau perkerasan. Green street pada dasarnya adalah salah satu yang dapat membersihkan dan menyerap hasil limpasan air hujan atau run-off sendiri melalui kombinasi yang seimbang dari teknik yang sama. Desain lanskap jalan kawasan yasmin ini bertujuan untuk memberikan inovasi desain Jalan K. H. Abdullah Bin Nuh sebagai jalur tata hijau berbasis Green Street dengan permasalahan yang ada pada tapak seperti terhambatnya saluran drainase dan dengan menerapkan sistem dari green street, diantaranya green infrastructure, complete street dan placemaking tools. Complete street merupakan desain jalan yang nyaman dan aman dengan pembagian jalur sirkulasi kendaraan bermotor dan sepeda dengan jelas. Prinsip placemaking ialah prinsip dimana desain yang dihasilkan harus memberikan identitas terhadap area tersebut. Hasil penelitian berupa desain lanskap jalan yang terdiri atas ruang pelayanan, identitas, kendaraan, pedestrian, penyangga dan konservasi. Tapak penelitian yang berada di Jalan K.H. Abdullah Bin Nuh terbagi dalam lima segmen dengan beragam macam konsep dan desain yang diterapkan sesuai dengan konsep green street. Konsep green street utama yang diterapkan pada tapak ini adalah rain garden yang berfungsi mebantu menyerap limpasan air hujan. Penelitian ini menghasilkan rencana tapak, rencana penanaman, detail potongan dan gambar ilustrasi desain.
\end{abstract}

Kata-kata Kunci: desain jalan, green street, green infrastructure, lanskap jalan

\section{LANDSCAPE DESIGN IN K.H. ABDULLAH BIN NUH STREET BASED ON GREEN STREET}

\begin{abstract}
Green Street is a critical innovation in managing water run-off from paving or pavement. Green street is one that can clean and absorb the results of rainwater runoff or its own through a balanced combination of the same technique. Landscape design for Yasmin area aims to provide innovative K.H. Abdullah Bin Nuh street design as Green Street-based green path with existing problems on tread such as drainage channel obstruction and by applying green street system, including green infrastructure, complete street, and placemaking tools. A complete street is a comfortable and safe road design with clear division of motor vehicle and bicycle circulation paths. The placemaking principle is the principle where the resulting design should provide an identity to the area. The result of the research is the design of the road landscape consisting of service space, character, vehicle, pedestrian, buffer, and conservation. The research site located at K.H. Abdullah Bin Nuh street is divided into five segments with various kinds of concepts and designs applied following green street concept. The main green street concept applied to this site is a rain garden
\end{abstract}


that serves to absorb rainwater runoff. This research produces site plan, planting plan, detail construction, and illustration design.

Keywords: design street, green street, green infrastructure, landscape street

\section{Pendahuluan}

Kota Bogor merupakan daerah kawasan yang memiliki curah hujan yang sangat tinggi sehingga dapat dijuluki sebagai "Kota Hujan". Hal tersebut sangat mempengaruhi kawasan di Kota Bogor terutama mengenai permukaan dataran di kawasan ini sehingga menjadi suatu permasalahan utama dari suatu tapak. Permasalahan pada saluran drainase pada Jalan Raya ini terjadi pada saat kegiatan overlay pada jalan di titik persimpangan menuju Jalan K.H. Sholeh Iskandar sehingga mengakibatkan aliran permukaan mengalir ke Jalan K.H. Abdullah Bin Nuh dan tidak luput dari faktor cuaca hujan yang terjadi di Kota Bogor. Permasalahan tersebut merupakan hal yang utama pada limpasan air hujan yang mengalir ke saluran drainase. Beberapa titik pada sepanjang jalan ini mengalami genangan air yang dapat mengakibatkan banjir yang dapat menutupi badan jalan sehingga perlu diberi solusi alternatif pada sistem drainase di Jalan K.H. Abdullah Bin Nuh.

Permasalahan tersebut perlu diatasi oleh penulis dengan memberikan alternatif solusi yaitu dengan membuat desain Jalan K.H. Abdullah Bin Nuh dengan aplikasi Green Street yang dapat mengelola resapan air. Konsep Green Street bekerja sebagai fasilitas penunjang untuk lanskap jalan yang memiliki tujuan umum untuk meningkatkan estetika dari aspek visual lanskap jalan dan tujuan khusus untuk membantu menyaring limpasan air hujan agar tidak terjadi genangan yang dapat menyebabkan banjir (Austin, 2014). Selain itu, konsep Green Street yang diterapkan pada area Jalan K.H. Abdullah Bin Nuh ini adalah Rain Garden guna selain berfungsi sebagai penyaring limpasan air hujan +juga berperan penting dalam estetika lanskap di area Jalan K.H. Abdullah Bin Nuh. Kemudian terdapat aplikasi Porous pavement yaitu perkerasan seperti jalan maupun area jalan yang dapat berfungsi menyerap limpasan air hujan dan dapat membantu penyerapan dari saluran drainase di area Jalan K.H. Abdullah Bin Nuh. Aplikasi Green Street ini merupakan aplikasi baru yang digunakan di mancanegara dengan harapan dapat diaplikasikan di Indonesia dan sebagai rekomendasi untuk Pemerintah Kota Bogor dalam menangani masalah banjir dan drainase.

Kota Bogor juga mengalami beberapa penyimpangan pada peruntukkan ruang terbuka kota karena fungsi awalnya telah mengalami perubahan. Salah satu penyimpangan tersebut ialah banyaknya fasilitas di kawasan jalan tidak terawat bahkan hingga dirusak oleh beberapa pengguna jalan yang tidak bertanggung jawab. Jalan yang merupakan jalur pergerakan manusia dan kendaraan adalah sarana transportasi yang penting dan sangat erat kaitannya dengan aktivitas yang ada di dalamnya maupun di sekitarnya (Simonds, 1983). Penggunaan jalan selain untuk kendaraan juga diperuntukkan bagi pejalan kaki dan pengguna sepeda. Di samping itu, ruang terbuka hijau jalan juga sangat mempengaruhi kenyamanan dalam aktivitas. Keberadaan tanaman di tepi jalan merupakan salah satu ruang terbuka hijau jalan guna dalam antisipasi peningkatan kenyamanan dan kualitas lanskap jalan.

Jalan K.H. Abdullah Bin Nuh merupakan kawasan yang memiliki potensi untuk menjadi Central Business District (CBD) karena laju gerak perekonomian, pemukiman dan jasa terkonsentrasi pada daerah ini. Menurut Rencana Tata Ruang Wilayah Kota Bogor Tahun 20102029, Jalan K.H. Abdullah Bin Nuh termasuk dalam wilayah Kecamatan Bogor Barat dan wilayah ini diperuntukkan sebagai kawasan perdagangan, perumahan, pendidikan dan jasa. Di sepanjang jalan ini terdapat perkantoran, ruko, toko-toko, kompleks perumahan, mall, sekolah, rumah sakit, dan pemukiman. Jalan ini merupakan kawasan perdagangan dengan lalu lintas yang ramai, baik lalu lintas kendaraan maupun lalu lintas pejalan kaki. Namun keberadaan jalan ini kurang baik dari segi struktur dan estetikanya seperti keadaan jalur pejalan kaki dan perkerasan yang rusak. Permasalahan 
lainnya yaitu pola tanaman di sekitar jalan tidak jelas sehingga nilai estetika pada jalan ini dinilai terlihat kurang memadai. Hal tersebut merupakan permasalahan dari aspek visual dan kenyamanan pengguna tapak. Tujuan penelitian ini adalah (1) mengidentifikasi dan menganalisis permasalahan pada Jalan K.H. Abdullah Bin Nuh; (2) mengetahui kesesuaian kriteria standar jalan pada Jalan K.H. Abdullah Bin Nuh dengan berbasis Green Street; dan (3) merancang dan membuat rekomendasi desain lanskap Jalan K.H. Abdullah Bin Nuh sebagai jalur tata hijau berbasis Green Street beserta detail konstruksi.

\section{Kajian Pustaka}

\section{Green Street}

Green Street merupakan jalan yang di desain untuk penyerapan limpasan air hujan yang dekat dengan sumber aliran air, menciptakan suasana yang lebih aktif dan ramah akan lingkungan. Tujuan dalam desain ini, terdapat tiga prinsip untuk desain Green Street yang telah diidentifikasi. Strategi dan manfaat yang terkait di setiap prinsip tersebut untuk membantu jalan yang berkelanjutan dan mensejahterakan masyarakat (Carlson et al, 2014).

1. Green Infrastucture: Menggunakan cara alami untuk membantu limpasan air mengalir ke sumbernya. Green Infrastructure merupakan sistem naturalisasi yang berfungsi untuk menyerap, evapotranspirasi dan mendaur ulang limpasan air hujan yang jatuh permukaan tanah. Green Infrastructure menggunakan vegetasi, tehnik tanah dan permukaan berpori untuk menangkap limpasan air hujan sebelum masuk ke dalam saluran pembuangan air.

2. Complete Streets: Membuat jalur sepeda dan jalur pedestrian yang ramah akan jalan. Complete Streets merupakan desain untuk semua pengguna jalan, jalan yang berlawanan terhadap pengguna kendaraan yang dominan. Prinsip ini menciptakan suasana yang aman, mudah dan nyaman bagi akses yang dilalui oleh semua pengguna, tentunya semua umur, kemampuan, pendapatan atau transportasi, memprioritaskan pada hidup sehat, keamanan dan kenyamanan bagi masyarakat setempat baik penghuni dan pengunjung yang ada di tapak.

3. Placemaking: Mendukung potensi sense of place. Prinsip ini yaitu menguatkan koneksi antara manusia dengan bagian dari suatu tempat yang mereka gunakan. Placemaking ini membuat ruang yang mencerminkan suatu identitas dan sejarah dari penduduknya, mengambil beberapa bentuk, dari taman berskala kecil hingga taman lingkungan yang berskala besar. Gambar contoh aplikasi Green Street berupa Rain Garden dapat dilihat pada Gambar 1.

Green Street bersifat multifungsi dan desain yang kompleks secara geometris, dan semakin diakui sebagai konsep inti dalam keberlanjutan. jalan-jalan konvensional dan pipa drainase dirancang dengan pola geometri sederhana untuk mengoptimalkan satu fungsi eksklusif (permukaan datar untuk laju kendaraan, silinder sederhana untuk pembuangan air). Seperti ekosistem, Jalur hijau jalan adalah langkah menuju jumlah ekosistem 'geometris' yang kompleks, keterbukaan fungsional, dan keberagaman.

\section{Metode Penelitian}

Metode yang digunakan dalam penelitian ini adalah metode analisis deskriptif kualitatif yang mengacu pada tahapan proses perancangan lengkap Simonds (1983). Proses perancangan dibagi ke dalam empat tahap, yaitu; persiapan awal, inventarisasi, analisis dan sintesis, dan pembuatan konsep. Batasan penelitan ini adalah untuk menghasilkan produk berupa gambar teknis. Adapun gambar teknis tersebut meliputi gambar rencana blok, rencana tapak, detil potongan, detil elemen lanskap, serta gambar ilustrasi tapak. Produk yang dihasilkan dari penelitian ini berupa beberapa desain lanskap Jalan K.H. Abdullah Bin Nuh dengan berfokus pada studi mengenai desain lanskap untuk resapan air hujan menggunakan green street. 


\section{Persiapan Awal}

Untuk mempermudah proses penelitian dan penggambaran peta, sebelum dilakukan pengambilan data, persiapan awal pada penelitian ini dengan membagi segmen yang dibagi menjadi beberapa titik. Pembagian segmen dilakukan berdasarkan jarak sepanjang jalan, yaitu $\pm 400-600 \mathrm{~m}$ di setiap segmen dengan jarak keseluruhan pada tapak sepanjang $\pm 2200 \mathrm{~m}$. Pembagian segmen lokasi penelitian dapat dilihat pada Gambar 3. Masing-masing segmen merupakan bagian dari Jalan K.H. Abdullah Bin Nuh yang berlokasi pada:

1. Segmen 1 (utara: area komersil; selatan: area komersil; barat: simpang semplak; timur: segmen 2)

2. Segmen 2 (utara: area komersil dan permukiman; selatan: area permukiman; barat: segmen 1; timur: segmen 3)

3. Segmen 3 (utara: area komersil dan permukiman; selatan: area permukiman; barat: segmen 2; timur: segmen 4)

4. Segmen 4 (utara: area komersil; selatan: area permukiman; barat: segmen 3; timur: segmen 5)

5. Segmen 5 (utara: area komersil; selatan: area komersil; barat: segmen 4; timur: simpang Jalan Baru)

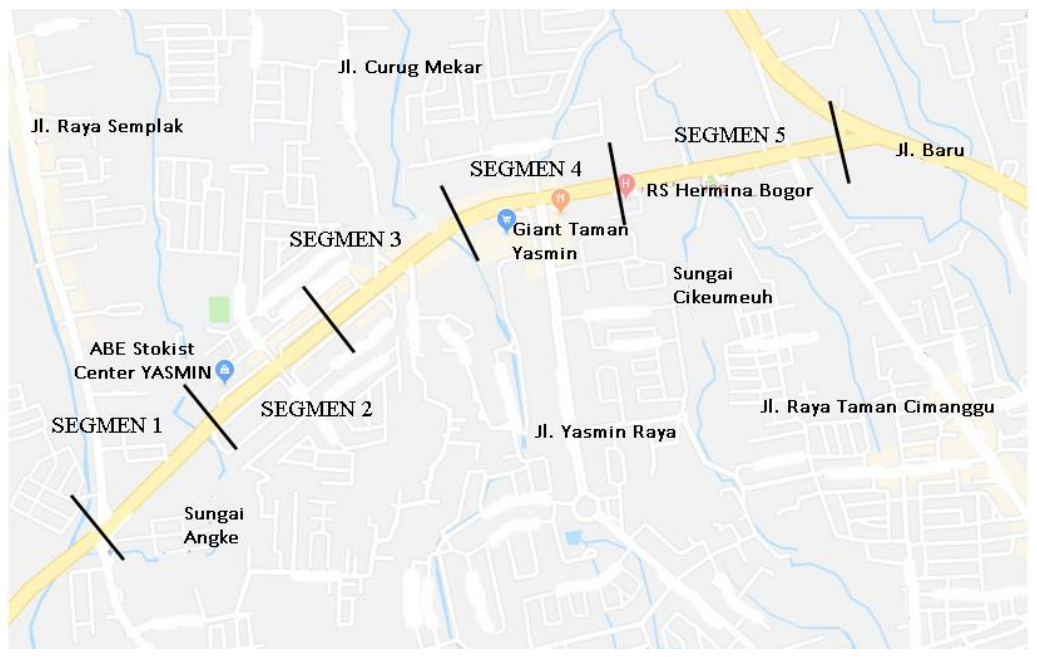

Gambar 2. Peta Pembagian Segmen

\section{Inventarisasi}

Sumber: Google maps

Tahap inventarisasi adalah pengumpulan data dan informasi pembentuk tapak berupa topografi, jenis tanah, iklim, drainase, tata guna lahan, sirkulasi dan aksesibilitas, vegetasi, satwa, pemandangan, fasilitas, utilitas, aktivitas, persepsi dan keinginan pemakai jalan, juga aturan-aturan dan kebijakan pemerintah.

Data primer berupa hasil observasi dan wawancara serta data sekunder diperoleh dari studi pustaka. Data primer diperoleh dari pengamatan visual, pencatatan dan dokumentasi untuk mendapatkan data fisik dan keadaan tapak yang sebenarnya. Hasil kuesioner responden yang berjumlah 40 orang selanjutnya dianalisis secara deskriptif untuk mengetahui keinginan dan persepsi. Responden adalah pejalan kaki, pedagang kaki lima, penghuni yang tinggal di kawasan tersebut, orang yang bekerja di sisi jalan, pengguna kendaraan seperti kendaraan pribadi dan umum. 


\section{Analisis}

\section{Analisis Deskriptif Kualitatif}

Kondisi tapak diperhatikan dalam segi fasilitas, tata ruang, pengguna dari tapak, dan tata hijau atau vegetasi yang termasuk dalam elemen softscape. Segi fasilitas yang diperhatikan yaitu layak atau tidaknya fasilitas yang ada di area pedestrian seperti jalur pejalan kaki yang tidak diberi perkerasan, tidak ada lampu penerangan di area pejalan kaki sehingga tidak nyaman pada malam hari bagi yang sedang berjalan kaki, tidak ada kesan estetika di sepanjang jalan ini terutama pada area pejalan kaki.

\section{Analisis Kuantitatif}

Analisis yang diperoleh melalui data sekunder berupa hasil wawancara dan kuesioner dengan pengguna tapak terutama pejalan kaki yang sering menggunakan area tersebut. Jumlah responden terbatas sebanyak 40 orang secara acak. Aspek yang terdapat dalam wawancara dan kuesioner tersebut adalah bagaimana persepsi masyarakat setempat atau pengguna jalan mengenai kondisi tapak. Kemudian hasil dari responden tersebut diakumulasikan secara persentase chart.
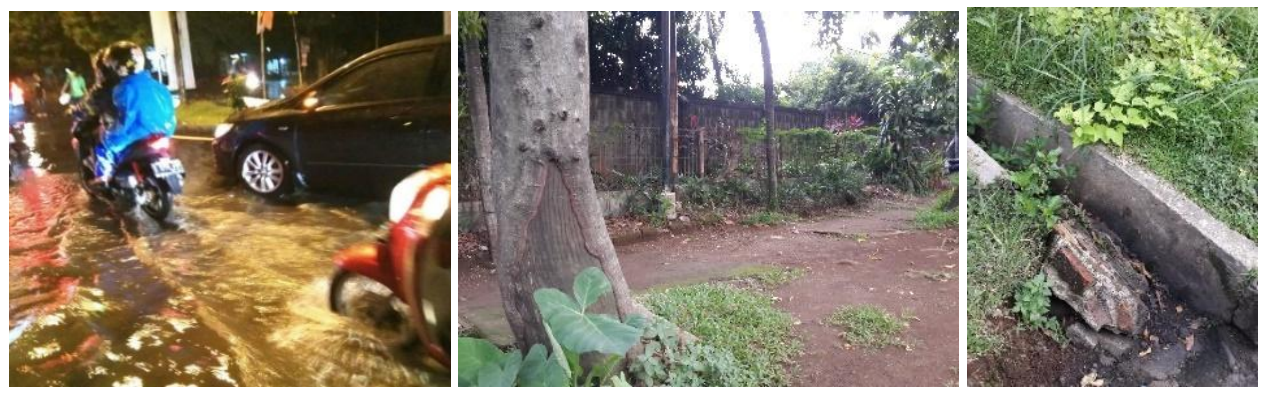

Gambar 3. Permasalahan Utama Pada Tapak

Sumber: Dokumentasi Penulis

\section{Sintesis}

Pada tahap sintesis dilakukan penyusunan dan dicari pengembangan potensi dan pemecahan masalah agar dapat diperoleh hasil yang sesuai dengan tujuan desain lanskap jalan. Potensi yang sudah ada dikembangkan sedangkan kendala dicari pemecahannya. Setelah itu dihasilkan alternatif ruang berdasarkan kriteria penilaian yang meliputi sirkulasi, kesesuaian ruang dengan sumberdaya tapak, vegetasi, keamanan, kenyamanan dan identitas.

\section{Konsep}

Dalam tahap konsep, terdapat konsep dasar dan desain. Konsep dasar berdasarkan fungsi utama pada tapak, konsep desain berdasarkan pola dari konsep dasar tertentu dan konsep pengembangan meliputi konsep tata ruang, konsep vegetasi dan konsep sirkulasi. Konsep tersebut dibuat berdasarkan pertimbangan dari hasil analisis potensi dan kendala pada tapak hingga sintesis untuk merencanakan desain pada tapak. Kemudian konsep pengembangan tersebut dikompositkan menjadi rencana blok yaitu penggabungan konsep ruang, vegetasi dan sirkulasi.

\section{Desain}

Desain mencakup beberapa proses, diantaranya pembuatan konsep desain yang akan diterapkan pada tapak. Desain memuat konsep green street yang bertujuan untuk meresapkan air pada area jalan. Hasil diagram konsep dikembangkan melalui desain skematis dalam bentuk rencana blok. Rencana blok merupakan desain awal tapak tanpa memerhatikan skala. Setelah itu dilakukan 
pembuatan site plan (rencana tapak) yang kemudian akan dihitung keuntungan resapan air dari hasil desain tersebut. Perhitungan keuntungan desain tersebut ialah dengan menghitung ulang nilai WQv dari hasil re-desain tapak, kemudian perhitungan volume air yang dapat diresapkan oleh sistem green infrastructure pada tapak, dimana WQv harus lebih rendah dari volume yang dapat diresapkan oleh sistem green infrastructure. Setelah pembuatan siteplan, selanjutnya ialah pembuatan potongan dan gambar detail elemen-elemen lanskap pada tapak. Perhitungan volume resapan oleh sistem green infrastructure pada tapak menurut (DEC 2010) dapat dilakukan dengan formula berikut:

$$
\begin{gathered}
W Q v \leq V s m+V d l+(D p \times A) \\
V s m=A \times D s m \times n s m \\
V d l=A \times D d l \times n d l
\end{gathered}
$$

$\begin{array}{lll}\text { Keterangan: } & \text { Vsm } & =\text { volume soil media }(\mathrm{ft} 3) \\ & \text { Vdl } & =\text { volume gravel media }(\mathrm{ft} 3) \\ \text { A } & =\text { area penerapan green infrastructure }(\mathrm{ft} 2) \\ \text { Dsm } & =\text { kedalaman soil media }(\mathrm{ft}) \\ \text { Ddl } & =\text { kedalaman layer drainase }(\mathrm{ft}) \\ \mathrm{Dp} & =\text { kedalaman diatas permukaan }(\mathrm{ft}) \\ \mathrm{nsm} & =\text { porositas soil media }(\geq 20 \%) \\ \mathrm{ndl} & =\text { porositas layer drainase }(\geq 40 \%)\end{array}$

\section{Hasil dan Pembahasan Kondisi Umum}

Jalan K.H. Abdullah Bin Nuh atau biasa disebut Jalan K.H. Abdullah Bin Nuh memiliki panjang $\pm 2200 \mathrm{~m}$, memanjang arah utara dan selatan dengan lebar DAMIJA (Daerah milik jalan) \pm 38 m. Menurut Rencana Umum Tata Ruang Kota (RUTRK) Kotamadya Bogor tahun 2005, peruntukan penggunaan lahan di kawasan Jalan K.H. Abdullah Bin Nuh adalah untuk kawasan perdagangan, perkantoran dan pemukiman (BAPPEDA, Kodya Bogor). Jalan K.H. Abdullah Bin Nuh atau Jalan K.H. Abdullah Bin Nuh berada pada ketinggian $\pm 220-232 \mathrm{~m}$ di atas permukaan laut. Jalan K.H. Abdullah Bin Nuh atau biasa disebut Jalan K.H. Abdullah Bin Nuh merupakan tipe Jalan Arteri Sekunder (BAPPEDA Kota Bogor, 2011). Jalan Arteri Sekunder adalah jalan yang melayani angkutan utama dengan ciri perjalanan jarak jauh dan kecepatan tinggi. Jumlah jalan masuk dibatasi seefisien mungkin untuk pelayanan distribusi masyarakat dalam kota. Jalan K.H. Abdullah Bin Nuh dapat dicapai melalui Jalan K.H. Sholeh Iskandar atau Jalan Raya Bubulak dan dari Jalan Semplak, Jalan Brigjen H. Saptadji Hadiprawira dan Jalan Raya Cibadak-Ciampea. Akses jalan yang lain adalah Jalan Pinang Raya, Jalan Palem Raya, Perumahan Taman Yasmin, Jalan Curug Mekar dan Jalan Yasmin Raya.

Sistem drainase yang terdapat di Jalan K.H. Abdullah Bin Nuh terdiri dari dua jenis yaitu saluran drainase tertutup pada sebelah utara dan selatan jalan dan saluran drainase terbuka pada sebelah timur jalan. Saluran drainase utama pada sebelah utara dan selatan jalan adalah Aliran Kali Cina yang berada di belakang atau di bawah bangunan. Pada sebelah utara dan selatan jalan saluran utama berupa saluran drainase terbuka. Terdapat 60 saluran drainase sekunder berupa catch drain yang berasal dari permukaan jalan kemudian mengalir menuju saluran utama sebagai pembuangan akhir yaitu Saluran Kali Cina dan Sungai Angke untuk sebelah utara dan selatan jalan.

Vegetasi yang dominan yang terdapat di Jalan K.H. Abdullah Bin Nuh adalah Palem raja (Roystenia regia), Kenari (Canarium commune L.). Selain itu terdapat juga vegetasi lain seperti Ki hujan (Samanea Saman), Palem putri (Veitchia Merillii), Palem ekor tupai (Wodyetia bifurcata), Nangka (Artocarpus heterophyllus), Pacing (Costus spicatus), Sambang colok (Aerva sanguinolenta), Lidah mertua (Sansevieria trifasciata), Pucuk merah (Oleina syzygium), Adam hawa 
(Rhoeo discolor), Soka (Ixora sp.) dan penutup tanah seperti Kacang hias (Arachis pintoi) dan Rumput gajah mini (Axonopus compressus).

\section{Analisis dan Sintesis}

Secara umum, kondisi tapak dengan berbagai potensi dan kendala perlu ditindaklanjuti kendala tersebut dan mengembangkan potensi pada lanskap Jalan K.H. Abdullah Bin Nuh. Keberadaan pedagang kaki lima dan parkir liar merupakan kendala utama pada tapak ini dengan memperhatikan kualitas visual tapak. Kemudian perlu beragam vegetasi pada tapak ini dikarenakan terkesan monoton bagi visual terhadap estetika lanskap jalan. Selanjutnya, permasalahan pada saluran drainase dengan terjadinya banjir oleh limpasan air hujan yang berlebih sehingga mengganggu aksesibilitas pada Jalan K.H. Abdullah Bin Nuh. Hal tersebut dapat menjadi fokus untuk menciptakan kualitas lanskap jalan pada aspek ekologi dan estetika dengan berbasis green street.

Sintesis dari hasil analisis pada tapak tersebut terdapat beberapa aspek yaitu estetika dan fungsional. Aspek estetika dari sintesis permasalahan tersebut terdiri dari vegetasi yang dipakai, yaitu berupa tanaman peneduh di sepanjang area pejalan kaki, tanaman estetik untuk keindahan dan tanaman fungsional yang terdiri dari tanaman rain garden yang berfungsi untuk membantu saluran drainase agar tidak menyebabkan tergenangnya jalan. Kemudian pada aspek fungsional desain tapak ini merancang ulang fasilitas umum pejalan kaki dengan konsep green street yang diaplikasikan pada halte, bench (tempat duduk) untuk pejalan kaki dan jalur sepeda.

\section{Konsep}

Konsep untuk perancangan ini berasal dari keadaan iklim di Indonesia yang tropis. Indonesia merupakan daerah tropika yang secara geografis berada di garis ekuator dan hanya memiliki dua musim, musim panas dan musim hujan. Konsep yang digunakan adalah tropikal ekologi yang merupakan perpaduan antara konsep arsitektur tropis dengan eco-design. Konsep tropikal ini akan digunakan pada median jalan dengan peletakan sculpture sebagai identitas jalan ini. Selain itu, jenis vegetasi yang terdapat di median jalan juga bersifat tropis seperti vegetasi eksisting yaitu palem raja yang akan dipertahankan, juga penambahan vegetasi yang bersifat tropikal sehingga sesuai dengan konsep tropikal di area median jalan.

Kemudian konsep ini berdasarkan dari permasalahan yang ada di tapak. Kota Bogor dikenal dengan Kota Hujan karena cenderung memiliki curah hujan yang sangat tinggi. Hal tersebut dapat mempengaruhi limpasan air hujan yang jatuh ke tanah tepatnya di sepanjang Jalan K.H. Abdullah Bin Nuh. Permasalahan tersebut terdapat beberapa titik di jalan ini yang mengalami kelebihan limpasan air sehingga menyebabkan banjir. Sehingga konsep yang diaplikasikan untuk tapak ini yaitu Green Street. Menurut Carlson et al (2014), terdapat tiga prinsip desain Green Street, yaitu Green infrastructure, Complete streets dan Placemaking. Aplikasi utama yang digunakan untuk tapak ini adalah Rain Garden yang terdapat bagian dari Green Infrastructure. Diagram konsep dasar dapat dilihat pada Gambar 5.
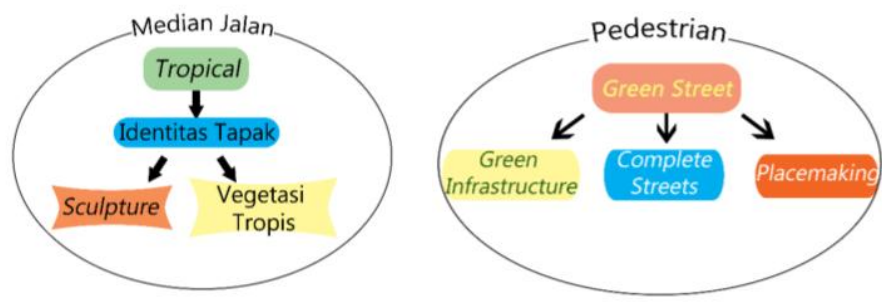

Gambar 4. Diagram konsep

Sumber: Analisis Penulis 


\section{Desain}

Proses desain merupakan tahap akhir dari rangkaian proses penelitian ini dengan hasil output berupa rencana tapak (site plan) pada masing-masing lokasi lanskap jalan. Desain yang diterapkan memadukan elemen hardscape dan softscape dengan rekayasa green street. Rencana sistem green stret pada tapak dapat dilihat pada Tabel 1.

Tabel 1. Rencana Sistem Green Infrastructures (GI), Complete Street (CS) Pada Tapak Dan Placemaking Tools Pada Tapak

\begin{tabular}{|c|c|c|c|}
\hline Lokasi & Green Infrastructure & $\begin{array}{l}\text { Complete Street } \\
\text { Tools }\end{array}$ & $\begin{array}{l}\text { Placemaking } \\
\text { Tools }\end{array}$ \\
\hline \multirow[t]{4}{*}{ Segmen 1} & Stormwater planter & & Bollard \\
\hline & Permeable pavers & & Parklet \\
\hline & Tree box filter & & \\
\hline & Green roof & & \\
\hline \multirow[t]{4}{*}{ Segmen 2} & Stormwater planter & Bike lanes & Bollard \\
\hline & Permeable pavers & Bike parking & Parklet \\
\hline & Runnel & Speed table & \\
\hline & Green roof & & \\
\hline \multirow[t]{5}{*}{ Segmen 3} & Stormwater planter & Bike lanes & Bollard \\
\hline & Permeable pavers & Bike parking & Parklet \\
\hline & Rain garden & Bump-out & \\
\hline & Runnel & Speed table & \\
\hline & Green roof & & \\
\hline \multirow[t]{5}{*}{ Segmen 4} & Stormwater planter & Bike lanes & Bollard \\
\hline & Permeable pavers & Bike parking & Parklet \\
\hline & Rain garden & Speed table & \\
\hline & Runnel & & \\
\hline & Green roof & & \\
\hline \multirow[t]{5}{*}{ Segmen 5} & Stormwater planter & & Bollard \\
\hline & Permeable pavers & & Parklet \\
\hline & Tree box filter & & \\
\hline & Runnel & & \\
\hline & Green roof & & \\
\hline
\end{tabular}

Sumber: Analisis Penulis

Kemudian prinsip sistem green street selain green infrastructure yakni complete streets tools dan placemaking tools sebagai penunjang fasilitas green streets bagi pengguna tapak khususnya pejalan kaki dan pengendaraa bermotor dengan berbasis ekologis dan fungsional. Kemudian ilustrasi penerapan sistem green street pada tapak dapat dilihat pada Gambar 5, 6 dan 7.

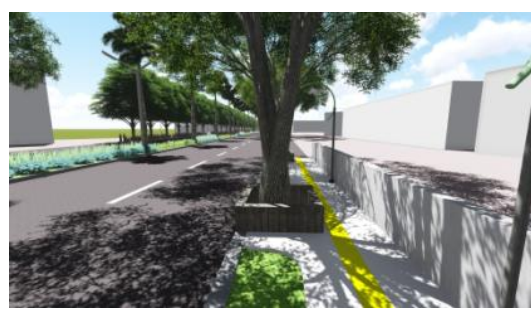

a. Stormwater planter

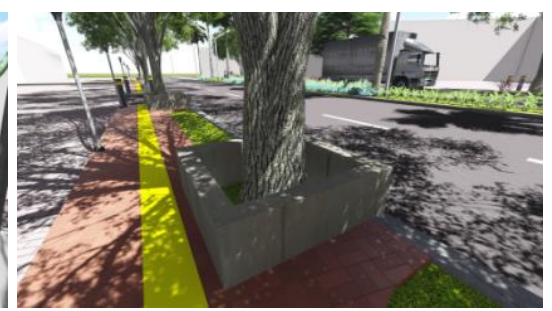

b. Tree box filter

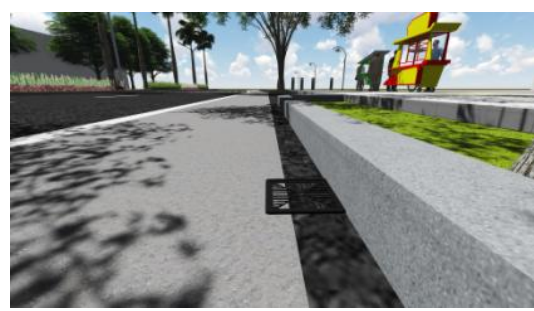

c. Runnel 


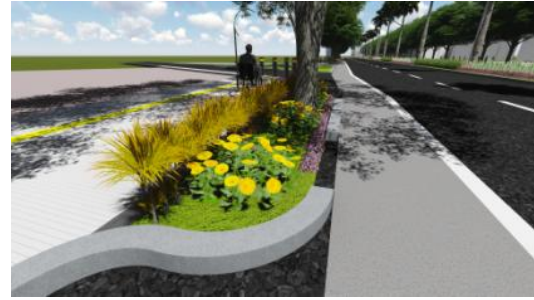

d. Rain garden

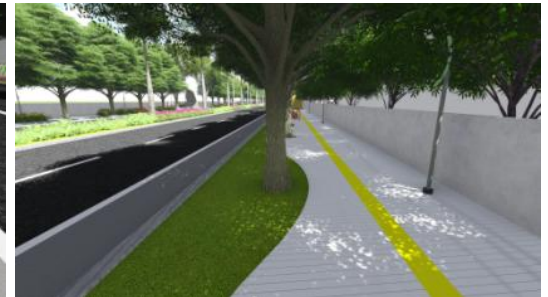

e. Porous pavement

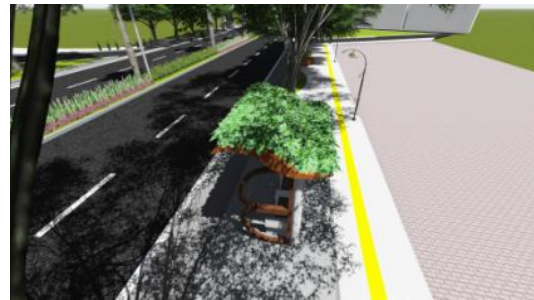

f. Green roof

Gambar 5. Ilustrasi Green Infrastructure Sumber: Analisis Penulis

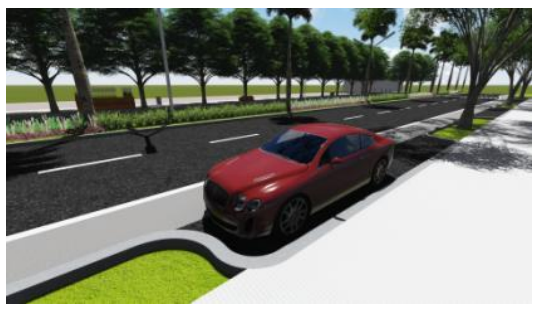

a. Bump-out parking

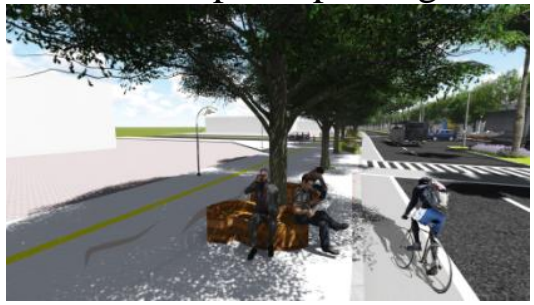

c. Bike lanes

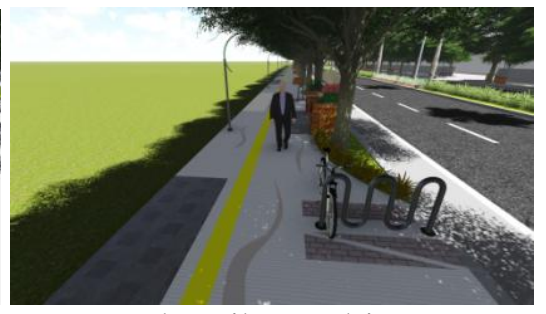

b. Bike parking

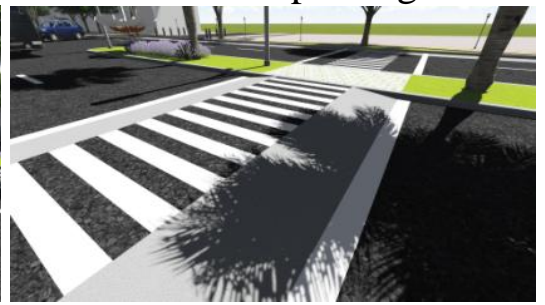

d. Speed table

Gambar 6. Ilustrasi Complete Street Tools Sumber: Analisis Penulis

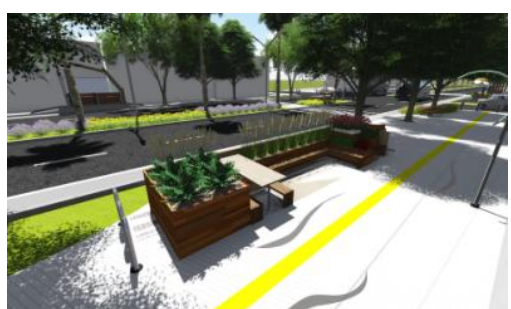

a. Parklet

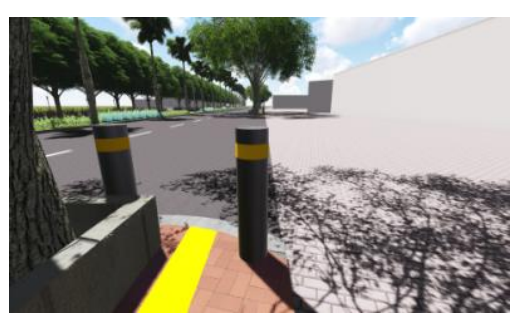

b. Bollard

Gambar 7. Ilustrasi placemaking tools

Sumber: Analisis Penulis

\section{Kesimpulan}

Berdasarkan permasalahan pada Jalan K. H. Abdullah Bin Nuh sebagai kawasan Central Business District (CBD), potensi yang terdapat pada tapak ini terdapat berbagai kebutuhan untuk kawasan bisnis, perkantoran dan perdagangan mengalami peningkatan. Kendala yang terdapat pada tapak ini yaitu banyaknya keberadaan pedagang kaki lima yang menggunakan jalur pejalan kaki secara liar. Hal tersebut perlu ditindaklanjuti melalui proses perencanaan desain lanskap jalan ini. Area PKL didesain dengan tertata rapi agar pengguna jalan yang ada di tapak merasa aman dan nyaman. 
Standar dan kriteria pada Jalan K. H. Abdullah Bin Nuh sesuai dengan penerapan sistem green street. Green street merupakan konsep yang sesuai untuk desain lanskap jalan terutama pada Jalan K. H. Abdullah Bin Nuh. Sistem Green Street didesain untuk meresapkan air hujan serta limpasan ke dalam tanah melalui rekayasa tanah dan penggunaan vegetasi. Penggunaan konsep green street pada desain lanskap Jalan K. H. Abdullah Bin Nuh ini sangat penting untuk digunakan, sebab persebaran permukaan jalan yang kedap air dapat menyebabkan limpasan air yang cukup tinggi. Air limpasan membawa dampak negatif, yaitu membawa sampah serta endapan, sehingga dapat merusak ekologi sungai. Jalur hijau hanya berfungsi meresapkan air hujan yang jatuh di atasnya, air limpasan pada jalan tidak dapat diresapkan ke dalam tanah, melainkan langsung dialirkan dengan menggunakan catch drain yang terbuat dari beton menuju drainase utama.

Tahap perancangan yang diterapkan pada Jalan K.H. Abdullah Bin Nuh dimulai dari tahap konsep. Konsep desain yang diambil untuk penelitian ini berdasarkan identitas dan tujuan lanskap jalan yang indah dan dinikmati oleh pengguna jalan. Konsep desain diterapkan pada bentukan hardscape dan softscape yang memiliki identitas tapak dan mendukung lanskap eksisting. Beberapa sistem green street yang dapat diterapkan pada jalan ialah tree box filter, stormwater planter, runnel, rain garden, bike lanes, bike parking, bump-out, speed table, bollard dan parklet. Prinsip green street yang diterapkan pada Jalan K. H. Abdullah Bin Nuh diterapkan menjadi rekomendasi desain lanskap jalan, serta detail konstruksi mengenai sistem green street dengan prinsip desainnya berupa green infrastructure, complete street tools dan placemaking tools.

\section{Daftar Pustaka}

[BAPPEDA] Badan Perencanaan dan Pembangunan Daerah. (2014). Rencana Pembangunan Jangka Menengah Kota Bogor Tahun 2015-2019. Bogor (ID): Badan Perencanaan dan Pembangunan Daerah Kota Bogor.

Austin G. (2014). Green Infrastructue for Landscape Planning. Glasgow: Bell and Bain Ltd.

Booth N K. (1983). Basic Elements of Landscape Architectural Design. Illinois (US): Waveland Press.
Carlson et al. (2014). Green Streets Guidebook for the City of Holyoke, Massachusetts. Winter: The Conway School

Departemen Pekerjaan Umum Direktorat Jenderal Bina Marga. (2008). Manual Kapasitas Jalan Indonesia (MKJI). Jakarta (ID) : Departemen Pekerjaan Umum.

Laurie. 1986. Pengantar kepada Arsitektur Pertamanan. Bandung: Intermatra

Simonds JO and Starke BW. (2006). Landscape Architecture. New York (US): McGraw HillBook Co. 